\title{
偏心旋回液体噴流によって攪拌される 円筒浴内の均一混合時間
}

\author{
井口 大亮* ·吉田 仁*2 ${ }^{*}$ 井口 学*3 \\ Mixing Time in a Cylindrical Bath Agitated by Off-centered Swirling Liquid Jet \\ Daisuke IGuCHI, Jin YoshIDA and Manabu IGUCHI
}

\section{1. 緒言}

鉄鋼精鍊プロセスにおいて，溶鋼とスラグの擋拌方法と して，主にArガス吹き込み，機械式撹拌，電磁擤拌が用 いられているが, 著者らは前に時間短縮や省エネルギー化， 低コスト化を図るために，新たな攪找方法として旋回液体 噴流を利用する方法を提案した ${ }^{1)}$ 。旋回液体噴流とは，円 筒浴および球形浴の底部から液体を吹き込んだときに生じ る噴流および浴内の液体の旋回運動であり，特定の浴深お よび吹き込み流量で発生する。液体噴流は，液体ではなく ガスを吹き込んだときに発生する旋回気泡噴流に比べ，旋 回に至るまでの時間が極めて短い。そこで著者らの研究室 では, 円筒容器の底部に吹き込み用の単孔ノズルを設置し たときに発生する旋回液体噴流についての詳細な調査を進

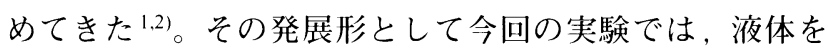
吹き込む単孔ノズルの位置を中心から遠ざけたときに発生 する旋回液体噴流が均一混合時間に及ぼす影響を調べた。

以前に行った旋回気泡噴流における均一混合時間の研究 において, 中心から容器内径 $D$ に対して1/6倍偏心した位 置に設置した場合が最も短くなったことから ${ }^{3)}$, 旋回液体 噴流の場合も同じ結果が期待できるからである。なお，前 報において ${ }^{2,4)}$ ，偏心した位置に吹き込みのノズルを設置 しても液体噴流の旋回運動は発生するが，その領域は中心 からノズルの位置を遠ざけるほど狭くなることなどを報告 したが，円滑な理解のために再度簡潔に触れたい。

\section{2. 実験条件}

水モデル実験として, 水を溶鋼に模擬し実験を行った。 円筒容器には透明なアクリル樹脂性のものを用い, その内 径 $D$ を $0.130,0.200,0.300 \mathrm{~m}$ とした。吹き込みに使用した単 孔ノズルは, その内径 $d_{n e n}$ が $5,10,13 \mathrm{~mm}$ のものを使用し
た。旋回運動の特性の調査は, 浴深 $H_{L}$ をいくつかの值に 固定して行うため, Fig. 1に示すように容器底部4隅に液 体引き抜き用のドレインノズルを4つ設置し，ポンプを用 いて容器内の液体を循環させることで浴深を一定に保っ た。吹き込みノズルの設置位置は, 容器底部中心から, 容 器内径 $D$ に対し $1 / 10,1 / 8,1 / 6,1 / 4$ 倍離れた位置とした。こ れをノズル位置 $R_{E}$ で表した。浴内の均一混合時間の測定 には $\mathrm{KCl}$ 水溶液を用いた。 $1 \mathrm{~mol} / \mathrm{L} の \mathrm{KCl}$ 水溶液を, 旋回 運動が定常状態に達したことを確認してから容器の中心に 水 $1 \mathrm{~L}$ 対して $1 \mathrm{~cm}^{3}$ の割合で投入し, 容器の底部および側 面から $10 \mathrm{~mm}$ 離れた位置に設置したセンサーで電気伝導度 の時間的変化を測定した。

\section{3. 実験結果}

偏心した位置から液体を噴流状態で吹き込むことで，旋 回の基本特性にどういった影響が現われ，均一混合時間と どのような関係があるのかを明らかにする必要がある。そ こで，旋回の発生する領域や，旋回の始まるまでの時間， 旋回の周期と偏心ノズル位置との関係について短く触れた い。

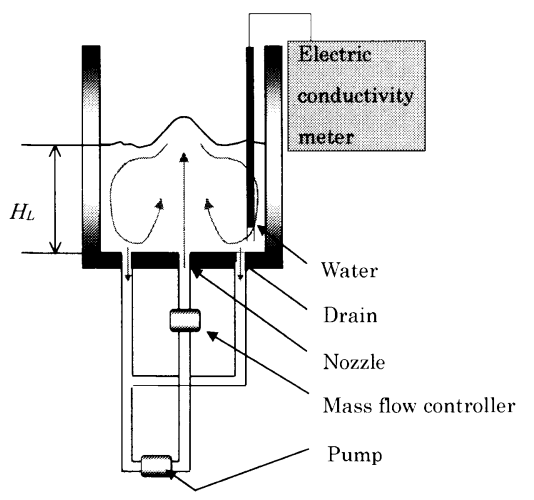

Fig. 1. Experimental apparatus. 


\section{$3 \cdot 1$ 旋回発生領域}

Fig. 2 に, 容器内径 $D=0.130 \mathrm{~m}$ のときの各ノズル位置に おける旋回発生領域を示す。なお，各々のプロットで囲ま れた内側で旋回が発生した。ノズルの設置位置が中心から 遠ざかるほど旋回の発生する領域が狭くなることがわか る。ここで整理に用いられている $R o_{m}$ は修正ロスビー数で あり, 次式で表される。容器内径やノズル内径が異なって も修正ロスビー数による整理法で，旋回発生領域を記述で きることが分かっている2)。

$$
R o_{m}=Q_{L}^{2} /\left(g d_{n e n}^{2} D^{3}\right)
$$

ここで $Q_{L}$ は液流量, $g$ は重力加速度である。なお，この無 次元数はフルード数の 1 種とみなすこともできる。

\section{$3 \cdot 2$ 旋回開始時間}

旋回開始時間 $T_{S S}$ は, 噴流を発生させてから旋回が定常 状態に達するまでの時間と定義した。なお，旋回発生領域 の境界のすぐ外側では旋回運動と往復運動が交互に起こ る。著者らは前に中心に吹き込みノズルを設置したときに 発生した旋回液体噴流の旋回開始時間の実験データから実

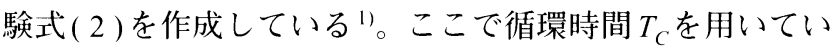
るが，これは吹き込みノズルで発生した噴流中の液体が容 器内を循環し，再度ノズル近傍に戻ってくるまでの時間の ことで, 容器内液体積 $V_{L}$ と噴流連行液流量 $Q_{L S}$ の比で表さ れる。旋回開始時間 $T_{S, S}$ と循環時間 $T_{C}$ を無次元化した結果, $T_{S S}$ の測定值は実験式 ( 2 )の $\pm 50 \%$ の偏差で近似できるこ とが分かっているい。

$$
\begin{aligned}
& T_{S, S}(g / D)^{0.5}=0.253\left[T_{C}(g / D)^{0.5}\right]^{1.75} \\
& T_{C}=V_{L} / Q_{L S}=\pi D^{2} d_{n e n} /\left(1.2 Q_{L}\right) \\
& V_{L}=\pi D^{2} H_{L} / 4 \\
& Q_{L S}=0.3 Q_{L} H_{L} / d_{n e n}
\end{aligned}
$$

実験式と比較を行うため，容器内径 $D$ が $0.130 \mathrm{~m}$ のとき の各ノズル位置 $R_{E}$ における旋回開始時間 $T_{S S}$ の実験データ をFig. 3 に示す。ノズルを偏心させた位置に設置しても， 旋回開始時間にほとんど影響を及ぼしていないことがわか る。ここには示していないが, 各容器内径の実験データを 無次元化したところ，同様な結果となった。

\section{$3 \cdot 3$ 旋回周期}

著者らの以前の研究で, 円筒容器を外部から加振した際 に発生する回転スロッシングの振動周期と，旋回液体噴流 の旋回周期は一致するという結果を得た ${ }^{5-7) 。 F i g . ~} 4$ に示さ れている実線は，回転スロッシングの振動周期，つまり容 器を加振したときの旋回液体噴流の理論式である ${ }^{7}$ 。どの ノズル位置における旋回周期の実験データも理論式でよく 近似ができている。容器内径を換えた場合でも同様の結果

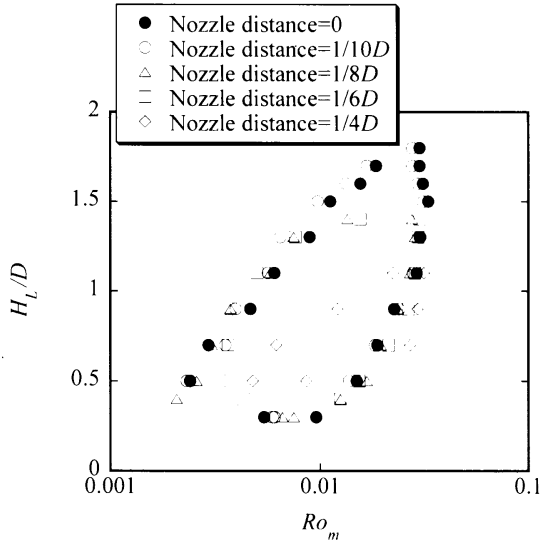

Fig. 2. Boundary of occurrence region of swirl motion $\left[D=0.130 \mathrm{~m}, d_{\text {nen }}=13 \mathrm{~mm}\right]$.

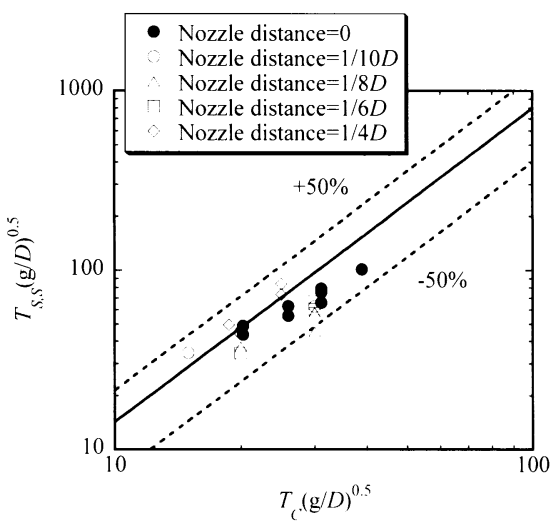

Fig. 3. Starting time of swirl motion, $T_{S S S}[D=0.130 \mathrm{~m}]$.

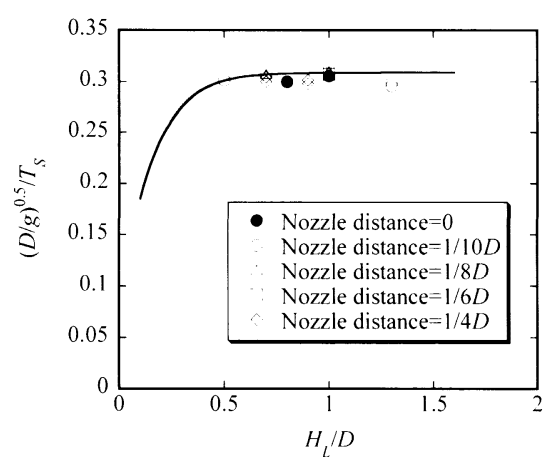

Fig. 4. Period of swirl motion, $T_{S}[D=0.130 \mathrm{~m}]$.

が得られた。

以上のことから，ノズル位置を中心から遠ざけることで 旋回現象が発生する領域は狭くなっていくが，旋回開始時 間や旋回周期といった時間的な基本特性にはほとんど影響 を及ぼさないことがわかる。

\section{$3 \cdot 4$ 均一混合時間}

浴内の均一混合時間を測定するにあたり，最も重要に なってくるのは浴内，配管内をあわせた総液体積である。 噴流によって旋回が生じている浴内では強い攪拌が行われ ているが，ポンプによる循環が行われている配管内では攪 拌効果は得られない。すなわち総液体積に対し，浴内の液 
Table 1 . Volumes of the bath, $V_{L}$, and pipe, $V_{\text {pipe. }}$

\begin{tabular}{|c|c|c|}
\hline Volume & $\begin{array}{r}V_{l}\left(\mathrm{~cm}^{3}\right) \\
\left(H_{l} / D=1.0\right)\end{array}$ & $V_{\text {pipe }}\left(\mathrm{cm}^{3}\right)$ \\
\hline 0.130 & 1700 & 1300 \\
\hline 0.200 & 6300 & 1800 \\
\hline 0.300 & 21200 & 2100 \\
\hline
\end{tabular}

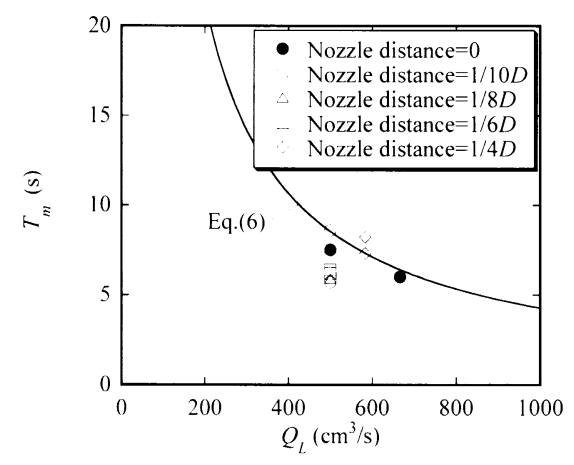

Fig. 5. Mixing time, $T_{m}\left[\mathrm{D}=0.300 \mathrm{~m}, H_{l} / D=0.7\right]$.

体積が大きいほど旋回液体噴流による撌拌効果は大きいと 考えられる。Table 1 に,アスペクト比 $H_{L} / D$ ととしたと きの, 今回の実験で使用した各容器における容器内液体積 $V_{L}$ と配管内液体積 $V_{\text {pipe }}$ を示す。容器内径が一番大きい $D=0.300 \mathrm{~m}$ ののが最も $V_{L} /\left(V_{L}+V_{\text {pipe }}\right)$ の比率が大きい。し

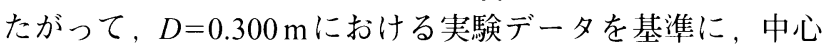
ノズルに対する実験式との比較を行った。ここで, 以前の 実験では均一混合時間にノズル内径は影響を及ぼさなかっ たことから，ノズル内径 $d_{n e n}$ は $13 \mathrm{~mm}$ に固定して行ってい る。

Fig. 5 に, 各ノズル位置のアスペクト比 $H_{L} / D=0.7$ におけ る均一混合時間の実験データを示す。罒中の実線は, 中心 にノズルを設置した時の均一混合時間の実験式 (6)であ る ${ }^{8)}$ 。

$$
\begin{aligned}
T_{m}= & 12\left[\left(V_{L}+V_{\text {pipe }}\right) / Q_{L}\right]\left(v_{L}^{2} / D^{3} g\right)^{0.15}\left(H_{L} / D\right)^{0.27} \\
& \left.\times\left[\left(V_{L}+V_{\text {pipe }}\right) / V_{L}\right]\right]^{1.6} \ldots \ldots \ldots \ldots \ldots \ldots \ldots \ldots \ldots \ldots \ldots \ldots \ldots \ldots \ldots
\end{aligned}
$$

ここで $v_{L}$ は使用している液体の動粘度である。この結果 から，気泡噴流の場合と同様に ${ }^{3)}, R_{E}$ が $1 / 6 D$ 程度偏心した 位置にノズルを設置したほうが均一混合時間は短くなるこ とがわかった。さらに理解を深めるために, 測定值と実験 式から求められる計算值との比と, ノズル位置の関係を Fig. 6 に示す。 $R_{E} /(D / 2)$ は偏心率と呼ばれる無次元数であ る。この結果から, 中心からノズル位置を遠ざけるほど均 一混合時間は短くなるが， $R_{E}=1 / 6 D$ をこえると逆に長く なるということがわかった。これは, 容器内径を 0.130 , $0.200 \mathrm{~m}$ にとったときにもみられた。

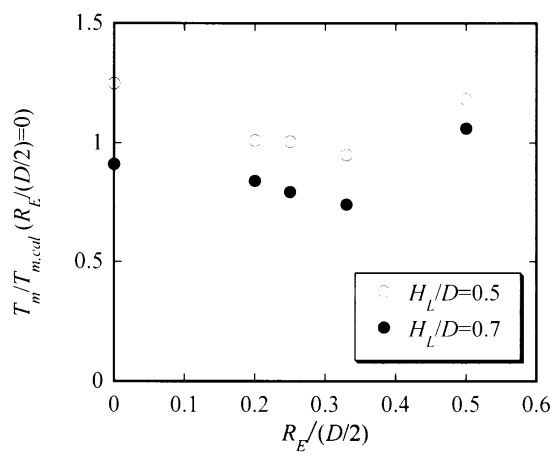

Fig. 6. Relationship between $T_{m} / T_{m \text {.cal }}\left(R_{E} /(D / 2)=0\right)$ and $R_{E} /(D / 2)[D=0.300 \mathrm{~m}]$.

\section{4. 結論}

ノズル位置は，旋回開始時間や旋回周期といった時間的 な基本特性にほとんど影響を及ぼさない。しかし，中心か ら遠ざかるほど旋回が発生する領域は狭くなる，つまり旋 回は起こりにくくなる。それに対し, 均一混合時間はノズ 儿位置を容器内径の $1 / 6$ 程度偏心させたときが, 最も短く なった。この結果は旋回気泡噴流の場合とよく一致してい る。

\section{記 号}

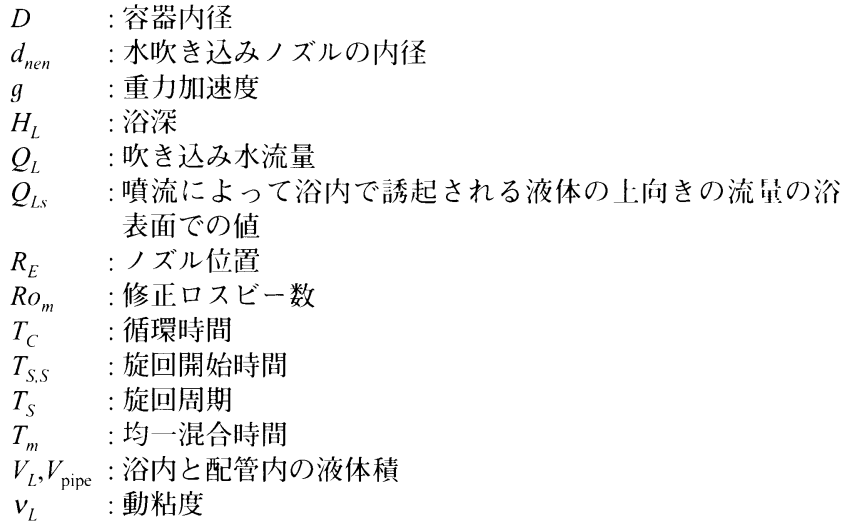

\section{文献}

1 ) D.Iguchi, J.,Yoshida and M.Iguchi: Tetsu-to-Hagané, 90 (2004), No. $6,357$.

2 ) D.Iguchi, M.Iguchi, Y.Sasaki and S.Yokoya: ISIJ Int., 44 (2004), 1451.

3 ) M.Iguchi, H.Ihira, Y.Takatsuka and S.Hosohara: ISIJ Int., 43 (2003), 1108.

4 ) D.Iguchi and M.Iguchi: Tetsu-to-Hagané, 91 (2005), 230.

5 ) M.Iguchi, Y.Eguchi, A.Kawasaki, S.Kitamura and K.Naito: ISIJ Int., 39 (1999), 767.

6 ) M.Iguchi, D.Iguchi, J.Yoshida: Mater. Trans., 45 (2004), No. 5, 1764.

7 ) A.Kimura and H.Ohashi: Trans. Jpn. Soc. Mech. Eng., 44 (1978), 3024.

8 ) J.,Yoshida, D.Iguchi and M.Iguchi: Tetsu-to-Hagané, 90 (2004), No. 6,371 . 